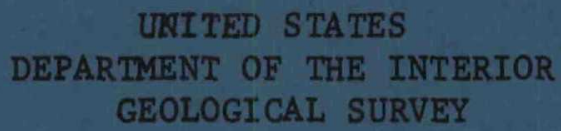

Federal Center, Denver, Colorado 80225

Summary geologic report on the UE20p exploratory hole, Area 20, Pahute Mesa, Nevada Test Site

\title{
Apri1 1969
}

Prepared Under

Contract AT(29-2)-474

for the

Nevada Operations office

U.S. Atomic Energy Commission 
This report was prepared as an account of Coverniment sponsored work. Neither the United States, nor the Compission, nor any person acting on behalf of the Counission:

a. Makes any varranty or representation, expressed or tmplied, with respect to the accuracy, completeness. or usefulness of the infornation contained in this eport, or that the use of any information, appar: tus, method of process disclosed in this report may not Infringe on privately ouned $x$ ights; or

b. Assumes any liabilities with respect to the use of, or for dameges resulting from the use of any inforor for damages resulting from the use of any infor-
wations, apparatus, method or process disclosed in this report

As noted in the above, "person acting on behalf of the Coumission" includes any employee or contractor of the Counisbion, ox empioyet ol such contractor, to the exte chat such ellpioyee os concractor of tine Comanision, of

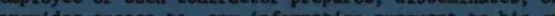
proviaes access to, any information pursuant to his enployment of contrace with the commisolesw, or this employ ent with such contractor. 


\section{DISCLAIMER}

This report was prepared as an account of work sponsored by an agency of the United States Government. Neither the United States Government nor any agency Thereof, nor any of their employees, makes any warranty, express or implied, or assumes any legal liability or responsibility for the accuracy, completeness, or usefulness of any information, apparatus, product, or process disclosed, or represents that its use would not infringe privately owned rights. Reference herein to any specific commercial product, process, or service by trade name, trademark, manufacturer, or otherwise does not necessarily constitute or imply its endorsement, recommendation, or favoring by the United States Government or any agency thereof. The views and opinions of authors expressed herein do not necessarily state or reflect those of the United States Government or any agency thereof. 


\section{DISCLAIMER}

Portions of this document may be illegible in electronic image products. Images are produced from the best available original document. 
Specia1 Studies -75

Apri1 1969
UNITED STATES

DEPARTMENT OF THE INTERIOR

GEOLOGICAL SURVEY

Special Projects Branch

USGS-474-15

Federal Center, Denver, Colorado 80225

SUMMARY GEOLOGIC REPORT ON THE UE20P EXPLORATORY HOLE, AREA 20, PAHUTE MESA, NEVADA TEST SITE

By

Evan C. Jenkins

Abstract

Exploratory drill hole, UE20p, was drilled to a total depth of 5,000 feet. Serious caving produced fill and bridge problems that necessitated the drilling of a side-track drill hole to a total depth of 4,480 feet. The caving problems may be attributed almost entirely to extreme alteration of the rock, probably by hydrothermal solutions, that thoroughly weakened it. Major units in UE20p were correlatable to a depth of 3,326 feet with units in UE20j and Pahute Mesa Exploratory Hole No. 2. Below that depth alteration is similar in all three drill holes and, as a result, correlation is difficult. Hydrologic tests show that the altered rocks should be extremely impermeable.

\section{Introduction}

Drill hole UE20p is located in the northwestern part of Area 20 on Pahute Mesa, Nevada Test Site, at Nevada coord., centra1 zone; N. $942,811.24 \mathrm{ft}$ and E. $542,022.30 \mathrm{ft}$ at a ground elevation of 5,552.98 feet above mean sea level. It is 13,450 feet east-southeast of Pahute Mesa Exploratory Hole No. 2 (PM No. 2) and 14,900 feet north-northeast of exploratory dri11 hole UE20j (fig. 1). UE20p was spudded January 11, 1968, and a total depth of 5,000 feet was reached May 18, 1968. However, because of bad hole conditions, a side-track hole was drilled using a Dyna-Drill from 3,000 feet to 4,480 feet in depth. The hole was cased with $103 / 4$-inch-diameter 


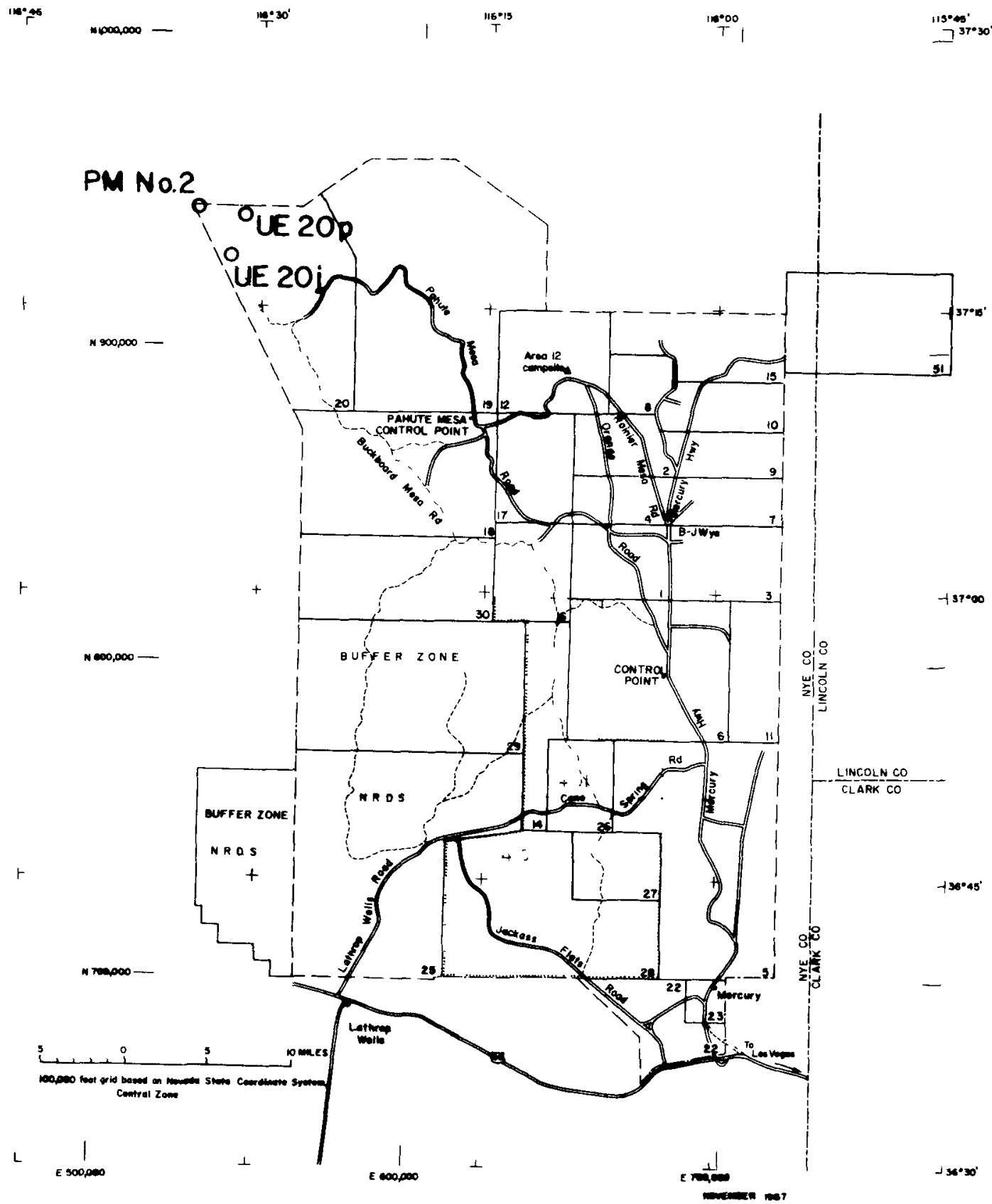

Figure 1.--Index map of the Nevada Test Site showing location of drill holes UE20p, UE20j, and Pahute Mesa Exploratory Hole No. 2. 
casing from the surface to 1,140 feet in depth, and the side-track hole was cased with 7 5/8-inch-diameter casing between the depths of 960 and 3,998 feet. UE20p was officially completed October 19, 1968.

\section{Stratigraphy and lithology}

A summary of stratigraphy and 1ithology of rocks penetrated in UE20p appears in table 1 , and probable correlations between UE20p and two other dri11 holes, UE20j and PM No. 2 appear in figure 2 . A graphic lithologic log of UE20p containing physical property data is presented in figure 3 (in pocket). Detailed descriptions of units in UE20p to a depth of 1,930 feet are the same as detailed lithologic descriptions to a depth of 980 feet in PM No. 2 (Hasler and Byers, 1965) and to a depth of 2,417 feet in UE20j (Hasler, 1965). The stratigraphy of PM No. 2 and UE20j has been updated recently by Orkild. (1968).

From the 1,930-foot depth to the depth of 3,326 feet, rhyolite lava of Quartet Dome, a peralkaline lava flow, and peralkaline ash-flow and bedded tuffs occupy the interval that corresponds to that of the Tub Spring Member of the Belted Range Tuff in the other two drill holes (fig. 2). These rocks in UE20p, by their peralkaline character, are rocks of the Silent Canyon volcanic center, the base of which is at a depth of 3,326 feet.

UE20p, 1ike UE20j and PM No. 2, was drilled outside the buried Silent Canyon Caldera (Orkild, 1968), and consequently a11 three dril1 holes penetrated rocks that predate Silent Canyon rocks at a comparatively

\section{LEGAL NOTICE}

Thin roport was prepared as an account of Goveroment aponeored work. Netther the Unitod Statos, nor the Commission, nor any person actlag on behalf of the Commission: racy, completeness or uoefulness of the informatson contained in thin roport or that the use of any toformation, epparatus, method, or process diselosed in thio report may not intringe 
Table 1.--Stratigraphic and lithologic units penetrated in the UE20p dri11 hole, Area 20, Pahute Mesa, Nevada Test Site

Stratigraphic and lithologic unit

Thickness (feet)

Depth to base of unit (feet)

Thirsty Canyon Tuff

Trail Ridge Member and upper part of

Spearhead Member (no samples)

Ash-flow tuff-_...-

Vitric bedded tuff-

Unknown Unknown

Reworked bedded tuff$40+\quad 340$

$140 \quad 480$

Timber Mountain Tuff

Ammonia Tanks Member

Ash-flow tuff--.-.

120

600

Vitric bedded tuff-_.

Rainier Mesa Member

Ash-flow tuff--

690

1,320

Vitric bedded tuff--

Vitric to zeolitized bedded tuff-.----

110 1,480

Rocks of the Silent Canyon volcanic center

Belted Range Tuff

Grouse Canyon Member

Ash-flow tuff-..-

375

1,855

Zeólitized bedded tuff-_.

Rhyolite lava of Quartet Dome-...-

$\begin{array}{rr}75 & 1,930 \\ 410 & 2,340\end{array}$


Table 1.--Stratigraphic and 1ithologic units penetrated in the UE20p drill hole, Area 20, Pahute Mesa,

Nevada Test Site--Continued

\begin{tabular}{|c|c|c|}
\hline Stratigraphic and lithologic unit & $\begin{array}{c}\text { Thickness } \\
\text { (feet) }\end{array}$ & $\begin{array}{l}\text { Depth to base } \\
\text { of unit (feet) }\end{array}$ \\
\hline \multicolumn{3}{|l|}{$\begin{array}{l}\text { Rocks of the Silent Canyon volcanic } \\
\text { center--Continued }\end{array}$} \\
\hline $\begin{array}{l}\text { Peralkaline lava flow } \\
\text { Interbedded ash-flow and minor bedded }\end{array}$ & 470 & 2,810 \\
\hline tuff-c-n & 516 & 3,326 \\
\hline \multicolumn{3}{|l|}{ Pre-Silent Canyon rocks } \\
\hline Rhyolitic lava flow & 54 & 3,380 \\
\hline Fraction Tuff(?) & & \\
\hline Ash-flow tuff & 290 & 3,670 \\
\hline Ash-flow tuff- & 60 & 3,730 \\
\hline Ash-flow tuff- & 50 & 3,780 \\
\hline Ash-flow tuff-n & 90 & 3,870 \\
\hline Interbedded ash-flow and bedded tuff--- & $1,130+$ & $5,000+$ \\
\hline
\end{tabular}


DEPARTMENT OF THE INTERIOR

UNITED STATES GEOLOGICAL SURVEY
USGS $-474-15$

Specral Studies -75

UE $20 \mathbf{j}$

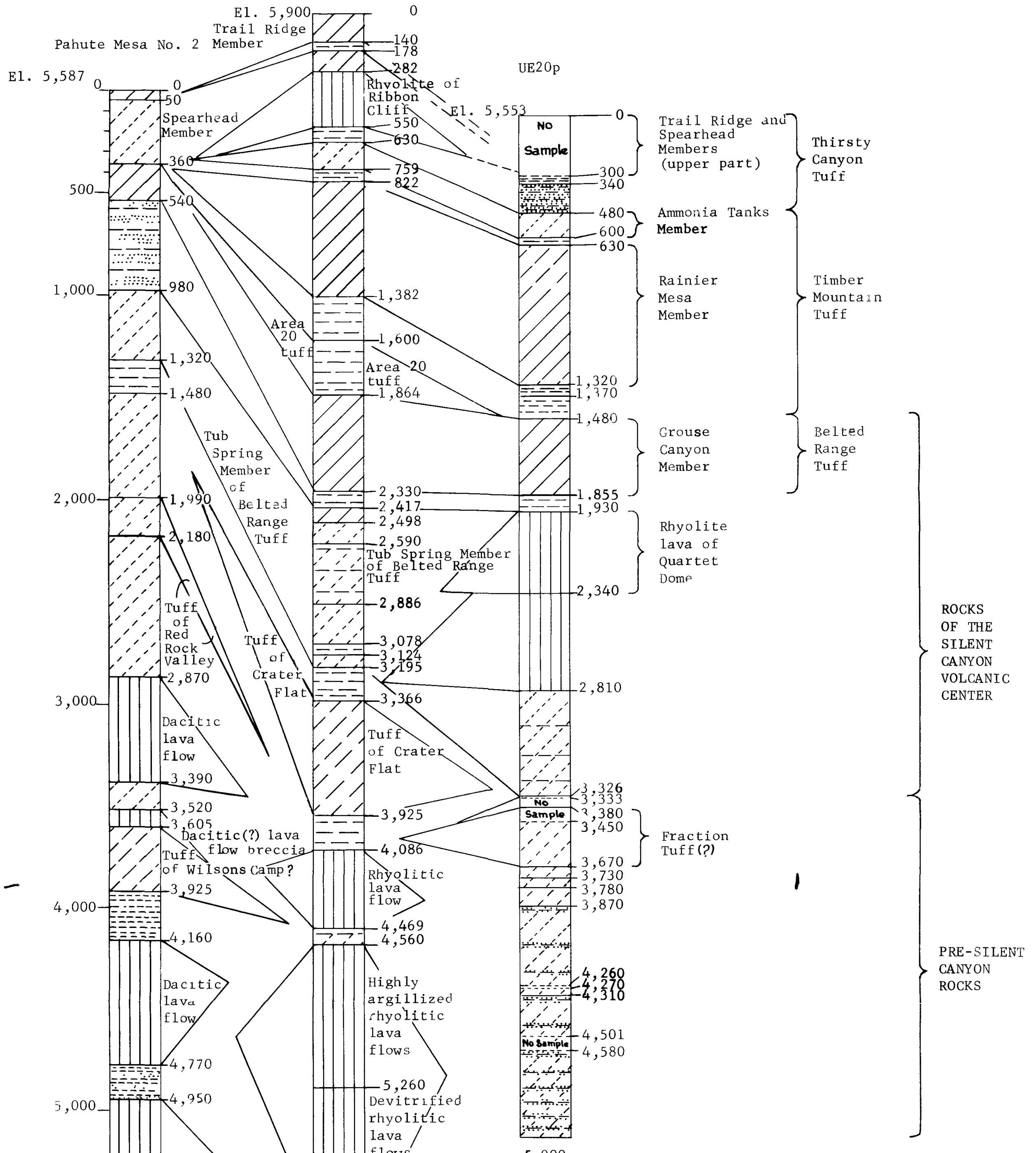
Mesa. Nevada Test Site. 
sha1low depth. UE20p, UE20j, and PM No. 2 drilled through the base of Silent Canyon rocks at depths of 3,326, 3,195, and 1,320 feet, respectively (fig. 2) but UE20f, drilled within the buried caldera, did not drill through the base of Silent Canyon rocks until the depth of 10,887 feet was reached (Orkild, 1968, p. 52).

In UE20p, UE20j, and PM No. 2, the major rock type encountered in pre-Silent Canyon rocks is different in each hole (fig. 2): In UE20p, the major rock type below Silent Canyon rocks is ash-flow and bedded tuff but in PM No. 2, the rock is mostly dacitic lava flow (see fig. 2); in UE20j, the major rock type is almost evenly divided between rhyolitic lava flow and tuff. Recognizable ash-flow tuff units are also different: tuff of Red Rock Valley and tuff of Wilsons Camp(?) are found in PM No. 2, tuff of Crater Flat in UE20j, and Fraction Tuff(?) in UE20p.

The alteration of pre-Silent Canyon rocks in all three drill holes, however, is quite similar. The tuffs are zeolitized and mostly argillized, and in places silicification and carbonatization have occurred. The lava flows which were altered are argillized in UE20j and in the dacites of PM No. 2 argillization, carbonatization, and silicification have occurred. Pyrite is present as tiny disseminated cubes and glomerocrysts throughout much of the pre-Silent Canyon rock. The type and extent of alteration in the three drill holes suggest hydrothermal alteration, and the abnormally high temperature gradient in this part of Pahute Mesa may indicate fairly recent hydrothermal activity. However, because the severe alteration is limited to pre-Silent Canyon rocks, it is probable that this alteration took place prior to the eruption of Silent Canyon rocks. 
Evidence for the presence of the lava flow at the top of the preSilent Canyon rocks in UE20p, depths 3,326-3,380 feet, is somewhat questionable. The only samples from this interval were taken between the depths of 3,326 and 3,333 feet (figs. 2 and 3). These samples, although thoroughly contaminated with up-hole cuttings, are dominantly rhyolitic lava-flow chips that are not peralkaline but probably are calcalkaline based on microscopic examination and heavy mineral separation and spectrographic analyses data. The drilling characteristics of the rock and the drilling-time log indicated an extremely tough, slowdrilling rock--drilling characteristics of unfractured lava-flow rock-to the 3,380-foot depth. These characteristics along with the thinness of the unit indicate that the unit could be the distal edge of a rhyolitic lava flow that probably originated in association within a caldera a few miles to the northeast.

The ash-flow tuff unit contiguously underlying the lava flow, between the depths of 3,380 and 3,670 feet, is tentatively identified as quartzfree Fraction Tuff. If this identification is correct, then this unit too probably came from a caldera to the northeast. However, the Fraction Tuff in that area is quartz-bearing, and no mention is made of a quartzfree or quartz-poor Fraction Tuff (Ekren and others, in preparation). The unit in UE20p resembles most a tuff unit at White Rock Spring in the Rainier Mesa quadrangle designated $\mathrm{Ti}_{5} \mathrm{w}_{5}$ (Gibbons and others, 1963), which has been tentatively identified as quartz-free Fraction Tuff (F. M. Byers, Jr., written commun., 1968). As is shown in figure 2, 
this unit in UE20p is older than both the tuff of Crater Flat in UE20 $j$ and tuff of Red Rock Valley in PM No. 2, but is younger than the tuff of Wilsons Camp(?) in PM No. 2

The entire sequence of rocks from the 3,450-foot depth to total depth $(5,000$ feet) has been zeolitized and argillized and silicification and carbonatization have cccurred in places. Most of the interval has been altered beyond recognition and is unsuitable for accurate correlation. Pyrite first appeared at the 3,710-foot depth and was found as glomerocrysts as well as tiny cubes dissemirated throughout the sequence to total depth.

One unit, between the depths of 3,730 and 3,780 feet, showed much less alteration than any of the rest of the sequence (fig. 3 ). This lack of alteration was first seen in the cuttings and was verified by electric logs. A thin vitrophyric zone is present from the 3,760 to the 3,770-foot depth, and the unit is mostly vitric from the depth of 3,770 feet to the base of the unit at 3,780 feet.

\section{Geologic settizg}

UE20p was spudded in the Trai1 Ridge Member of the Thirsty Canyon Tuff which dips very gently to the northwest. The drill hole is located on a gently northward-sloping, low topographic ridge and is on the slightly dissected northern edge of Pahute Mesa that borders on Gold Flat.

The Thirsty Canyon Tuff finally leveled the topography in the extreme northwestern part of the Nevada Test Site. The Timber Mountain 
Tuff nearly leveled the paleotopography, but it did not quite cover the topographic high, or hill, that was present in the position of PM No. 2 (fig. 2). This topographic high was probably formed by the dacitic lava flows found in PM No. 2 and which existed from the time they were deposited, approximately 18 million years ago (Anderson and Ekren, 1968, p. 59), to Thirsty Canyon Tuff time, approximately 8 million years (Paul P. Orkild, written commun., 1966), a time span of $10 \mathrm{~m} \cdot \mathrm{y}$. Throughout this time span, several units managed to be deposited on the topographic high, and, indeed, some leveling of the paleotopography occurred. But it was not until the deposition of the Thirsty Canyon Tuff that the task was completed.

During the $10 \mathrm{~m} \cdot \mathrm{y}$. time span the Timber Mountain Tuff and the Grouse Canyon Member units were deposited in a nearly circular topographic low, or valley, which now encompasses the geographic location of UE20p (fig. 2). The lower part of the rocks of the silent Canyon caldera unit in UE20p suggests strongly that it represented a local topographic high during early Silent Canyon time because the Tub Spring Member of the Belted Range Tuff is not present in the drill hole. In its place are Quartet Dome and peralkaline lava flows as well as nonwelded ash-flow and bedded tuffs. Evidently, the Tub Spring ash-flow tuff was diverted from the UE20p position, or it did not have enough momentum to carry it over the top of the lava flows. It is doubtful, but possible, because of the short time span between the deposition of 
the underlying tuff of Crater Flat (UE20j, fig. 2), (13.0-13.9 m.y.) and the overlying Grouse Canyon Member of the Belted Range Tuff (13.8 m.y.) (Paul P. Orkild, written commun., 1966) that the Tub Spring Member was deposited over the lava flow and then eroded. Very few exposed faults are located near UE20p. The only major fault is 5,000 feet southeast of the drill hole and it may have vertical displacement as much as 300 feet. The fault is buried by alluvium at the point nearest the drill hole, but it can be traced southward through Thirsty Canyon rocks for approximately 5 miles. The northern terminations of three minor faults are 3,800 feet east, 3,800 feet southeast, and 5,400 feet west-southwest of UE20p. The vertical displacements of these faults at points nearest UE20p probably do not exceed 20 feet (Orkild and Sargent, 1967, fig. 1, sheet 1 ).

The northern termination of a trough of a synclinal flexure is 2,200 feet west of UE20p (Orkild and Sargent, 1967, fig. 1, sheet 1). The trough extends southward in the Thirsty Canyon Tuff for more than $61 / 2$ miles. The trend (north-northeast) and the length of the trough resemble trends and lengths of major faults on Pahute Mesa. The trough has been interpreted as the surface expression of a major buried scarp.

\section{Effect of lithology on drilling operations}

Sloughing and caving considerably complicated the drilling of UE20p. Most of the difficulty is a direct result of the lithologic 
character of the rock, and little difficulty can be attributed to drilling and management practices.

A total of 175 days was used to drill and to attempt to condition UE20p. Total depth of the original hole was reached in 71 days, but so much difficulty with fill and bridging occurred that a side-track, Dyna-Drill hole was drilled. The side-tracked hole was completed in 15 days, 16 days were used to $10 \mathrm{~g}$, set casing, and cement at the 3,998-foot depth, and 11 days were used to perform two series of hydrological tests, one for the main hole and the other for the sidetracked hole. Therefore, at least 62 days were used to clean out fill and bridges, cement caving zones, and clean or drill out cemented caving zones.

The most serious and time-consuming fill problems occurred at approximately the 3,700-foot depth and below. This depth is near the top of the most extensively argillized portion of the drill hole, and this type of alteration, argillization, probably weakened the rock to the point where it could not stand in the open hole. A sample from the 3,804-foot depth was X-rayed for clay content, and the sample contained 12-13 percent montmorillonite in a mixed-layered arrangement (L.G. Schultz, ora1 commun., 1968).

Any abrasion, washing, or other agitation while drilling would have further weakened drill-hole walls and thus add to caving conditions. 
Continual caving in less coherent units would tend to undermine more stable units and eventually cause caving in the more coherent units because of lack of support.

This is probably the condition existing in UE20p in two zones: 3,380-3,950 feet and 4,400-5,000 feet and deeper. The zone between the depths of 3,950 and 4,400 feet seems to possess strength enough to stand in the open hole. Evidently, the only method to alleviate problems of this kind is to drill through the caving zone as quickly as possible, then case or cement the zone so that it cannot cave. The hole problems seemed to worsen as drilling continued, so the time the rock must stand in the open hole seems to be a factor.

Drilling and management practices probably contributed to hole problems, but they only aggravated the situation instead of initiating the problems or being the overt cause of them.

Between the depths of 1,300 and 2,370 feet, caliper logs show a peculiar sine wave pattern containing a period ranging from 57 to 168 feet and averaging 97 feet. The pattern seems to be mainly independent of lithologic changes and is probably due to attempts to straighten the hole throughout the 1,070-foot interval. This activity left many pockets in the hole wall where cuttings could collect, resulting in a loss of sample while drilling. During trips, connections, and periods when the hole was secured, the stored cuttings could slide back into the hole and thereby aggravate fill and bridge problems. This is a very great possibility in UE20p as examination and comparison of successive 
caliper logs showed an increase of material on the lower lip of some pockets and erosion of the same relative position on other pockets without much evidence of further caving of the pockets (fig. 4). Cuttings stored and released periodically would contaminate lithologic samples, and contamination did occur throughout most of the drilling. The drill hole was secured 13 times and suspended three times during its active drilling history. Two of the three times the hole was suspended, the rig was moved to a new location for approximately 1 month each time. The only time that the practice of moving the rig off the hole, or securing the rig for a long period of time, should be condoned is when the hole has been cased or cemented. The first time the rig was moved, the hole was cased and cemented to 1,140 feet, total depth at that time, and no problems developed when drilling began again. The second time, still approximately 55 feet above the bad caving zone, 2,186 feet of open hole was left, and on reentry 31 feet of fill was found.

The third time the rig was moved was after total depth $(5,000$ feet) had been reached, and the fight to keep the hole free of fill and bridges was well under way; 3,860 feet of ofen hole was standing. After 29 days, caliper loggers found the first bridge at the 2,349-foot depth. The third day after the rig returned, the crew cleaned out 1,248 feet of fill before cementing an actively caving zone. Lengthy secured or suspended periods did not initiate caving and fil1 probjems, but they must have added to the problems to some extent. 


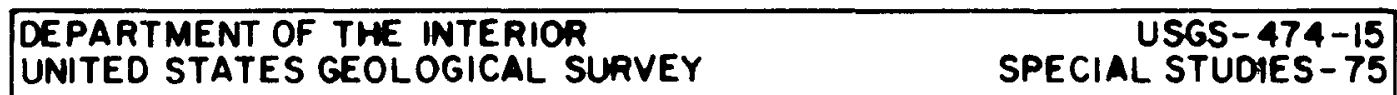

•

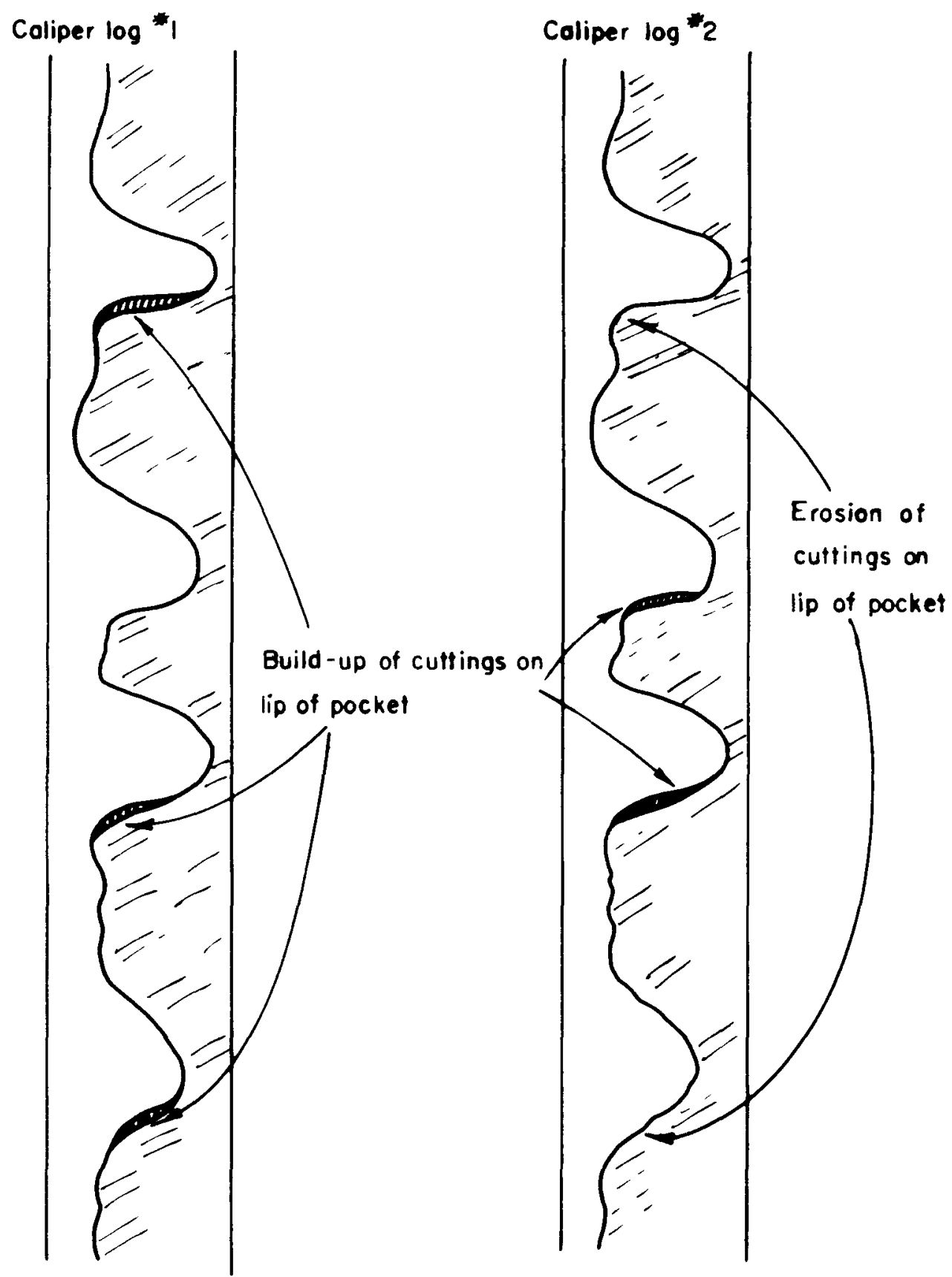

Figure 4.--Diagrammatic illustration of Caliper logs showing alternate collection and release of cuttings in pockets of the hole wall 


\section{Hyd rology}

The hydrology of drill hole UE20p is discussed in detail in an interoffice report by J. E. Weir, Jr., dated October 30, 1968. A summary of pertinent data appears in table 2 .

The report deals almost exclusively with a series of tests conducted October 1-4, 1968, in the side-tracked hole. Tests were performed in the main drill hole August 12-19, 1968, but the results of these tests were so poor and inconclusive, because of adverse drill hole conditions, that they were considered to be nearly valueless. As shown in table 2 , the relative specific capacity values are extremely low. According to Weir, these are the results one would expect from testing cement or grout, not country rock. It is possible that cement could have permeated the rock to yield results of this nature near the casing shoe at the 3,998-foot depth, but it is highly unlikely far below the shoe. It is also unlikely that cement could have permeated from the main drill hole to the side-tracked hole. It is much more probable that the tightness of the rock is due to the extreme alteration of the rock, and this seems to be verified by electric logs. If, however, the impervicusness of the rock is due to natural causes, it is the most impervious rock yet tested on Pahute Mesa 。

Temperature logs indicate two possible zones of bore hole cross flow. The major zone is from 1,140 to 3,000 feet in depth. This same zone was found to be a highly productive aquifer during hydrology tests. The other zone is minor, and it exists between the depths of 4,090 and 4,115 feet. 
Table 2.--Summary of hydraulic tests of hole UE20p, October 1-4, 1968

LFrom interoffice report by J. E. Weir, Jr., dated October 30, $1968 . \overline{-}$

\begin{tabular}{|c|c|c|c|}
\hline $\begin{array}{c}\text { Interval tested } \\
\text { with packers } \\
\text { (depth below } \\
\text { land surface, } \\
\text { in feet) }\end{array}$ & $\begin{array}{l}\text { Method of } \\
\text { testing }\end{array}$ & $\begin{array}{l}\text { Relative specific } \\
\text { capacity (gpm per } \\
\text { foot of drawdown) }\end{array}$ & Remarks \\
\hline $3,880-4,040$ & Injection & $<0.001$ & $\begin{array}{l}\text { Testing casing shoe; } \\
\text { only about } 40 \text { feet of } \\
\text { open hole in straddle. }\end{array}$ \\
\hline $4,044-4,461$ & Injection & $<.002$ & $\begin{array}{l}\text { Test of most of open } \\
\text { hole. }\end{array}$ \\
\hline $4,038-4,198$ & Injection & .00025 & \multirow{3}{*}{$\begin{array}{l}\text { Swabbing unsuccessful } \\
\text { because of plugged } \\
\text { ports in tool. }\end{array}$} \\
\hline $4,196-4,356$ & Injection & .000066 & \\
\hline $4,360-4,461$ & Injection & .0000017 & \\
\hline
\end{tabular}


Static water level is at an elevation of 4,633.5 feet or 919.5 feet below land surface.

\section{Chamberable zones}

Water tests indicate any rock between the depths of 4,100 and 4,461 feet should be dry enough for good chambering (J. E. Weir, Jr., written commun., 1968). However, 1ithologic evidence shows the rock between the depths of 4,400 and 5,000 feet to be poor for chambering because of caving problems. Rock from 3,950 to 4,400 feet in depth should be favorable for chambering for it has low permeability and low caving potential. 
References cited

Anderson, R. E。, and Ekren, E. B., 1968, Widespread Miocene igneous rocks of intermediate composition, southern Nye County, Nevada, in Ecke1, Edwin B., editor, Nevada Test Site: Geo1. Soc. America, Mem。110, p. 57-63.

Ekren, E。 B., Anderson, R. E。, Rogers, C. Lo, and Noble, D. C., 1966, Geology of northern Nellis Air Force Bese Bombing and Gunnery Range, Nevada: U.S. Geol. Survey Prof. Paper 651, in preparation. Gibbons, A. B., Hinrichs, E. N., Hansen, W. R., and Lemke, R. W., 1963, Geology of the Rainier Mesa quadrangle, Nye County, Nevada: U.S. Geo1. Survey Geo1. Quad. Map GQ-215. Hasler, J.W., 1965, Preliminary report on the lithology of drill hole UE20j, Pahute Mesa, Nevada Test Site: U.S. Geo1. Survey Tech. Letter Special Studies I-35, $12 \mathrm{p}$. Hasler, J。W。, and Byers, F. M。, Jr., 1965, Preliminary report on the lithology of Pahute Mesa drill hole No. 2, Pahute Mesa, Nevada Test Site: U.S. Geo1. Survey Tech. Letter Special Studies I-39, $20 \mathrm{p}$ 。

Orki1d, Paul Po, 1968, Report of exploration progress, Pahute Mesa, period Ju1y 31, 1966 - January 31, 1968: U.S. Geo1. Survey Tech. Letter Special Studies $\mathrm{I}-23-16,68 \mathrm{p}$.

Orki1d, Paul P。, and Sargent, K. A., 1967, Geologic map of Pahute Mesa, Nevada Test Site, Nye County, Nevada: U.S. Geol. Survey Tech. Letter Special Studies $I-54,23 \mathrm{p}$. 
Distribution:

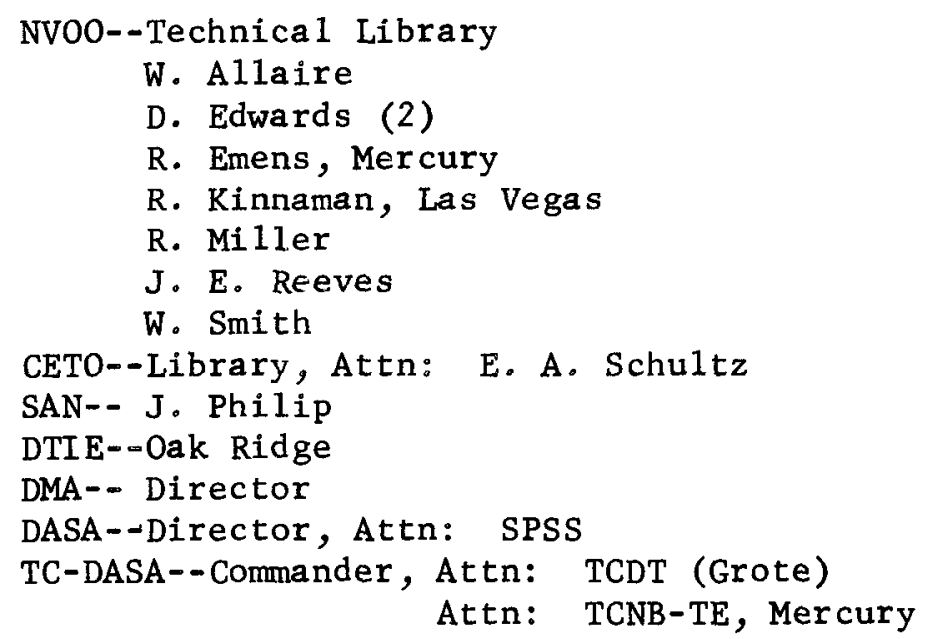

LASL- - R. Brad shaw

C. Browne

R. Campbe 11

R. Newman

W. Ogle

LRL-- Technical Information Dept.

R. McArthur

M. Nordyke

H. Reynolds

K. Ray, Mercury

T. Sterrett

C. Williams

SC-- B. Go Edwards, Mercury (2)

R. Statler 9133

W. Vollendorf 9133

W. Weart 9111

ERC- - Las Vegas

Virginia (8)

F\&S-- G. Bruesch, Mercury (3)

M. May, Las Vegas

H\&N-- Advance Planning, Las Vegas

Engineering Manager, Las Vegas

Resident Engineer, Mercury

II- Palo Alto Lab. (2)

WES $-\mathrm{W}$. Steinriede, Jr.

USGS $-D$. Lemmon

W. Pecora

Military Geology Branch

Chief Hydrologist, WRD, Attn: Office of Radiohydrology

WRD, Las Vegas (5)

Geologic Data Center, Mercury (15) 


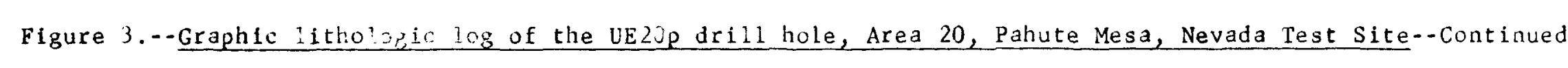

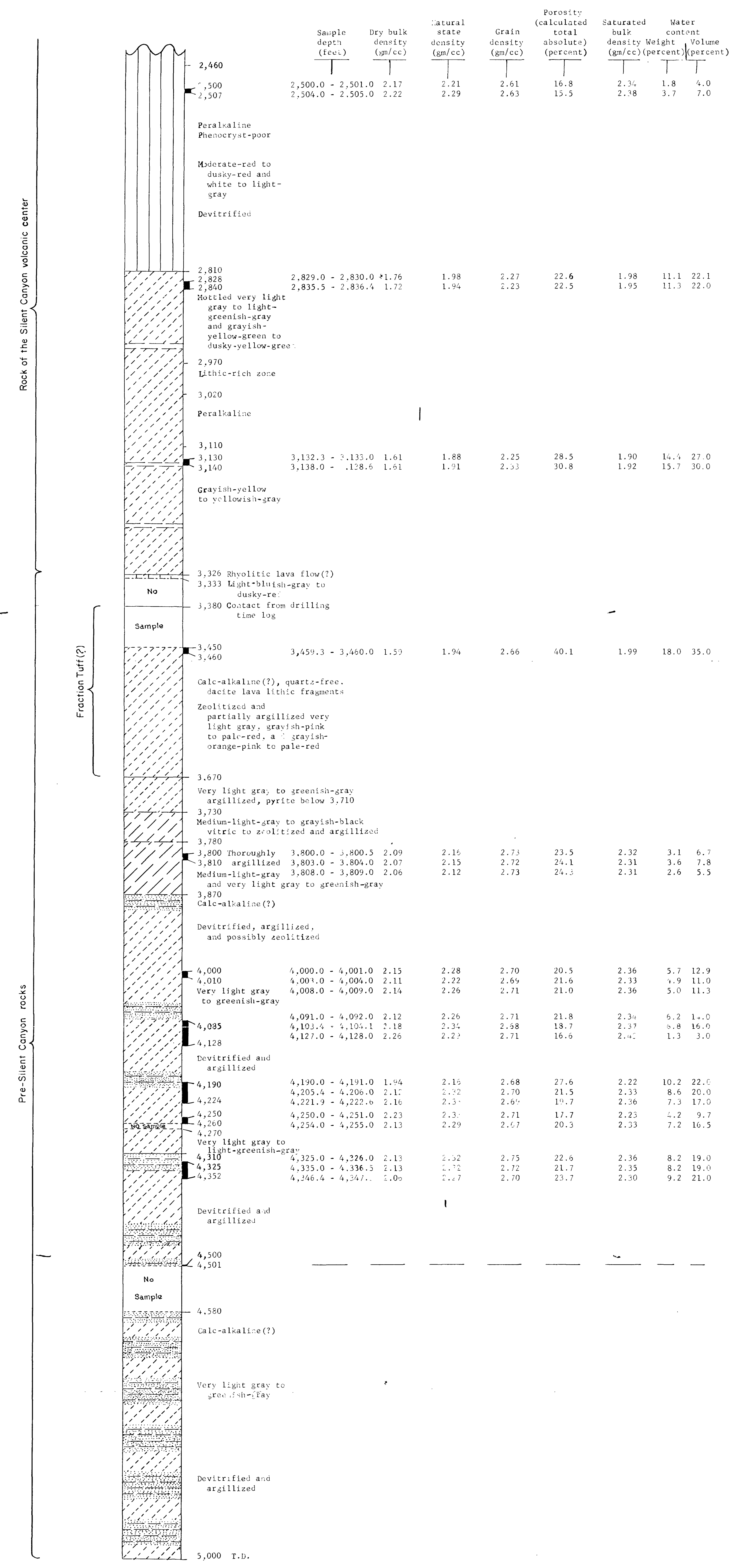


Figure 3.--Graphic 1ithologic log of the UR20p drill hole, Area 20, Pahute Mesa, Nevada Test Site

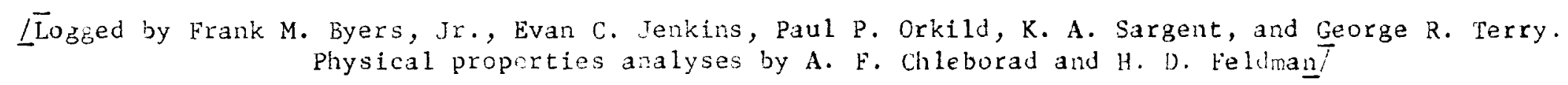
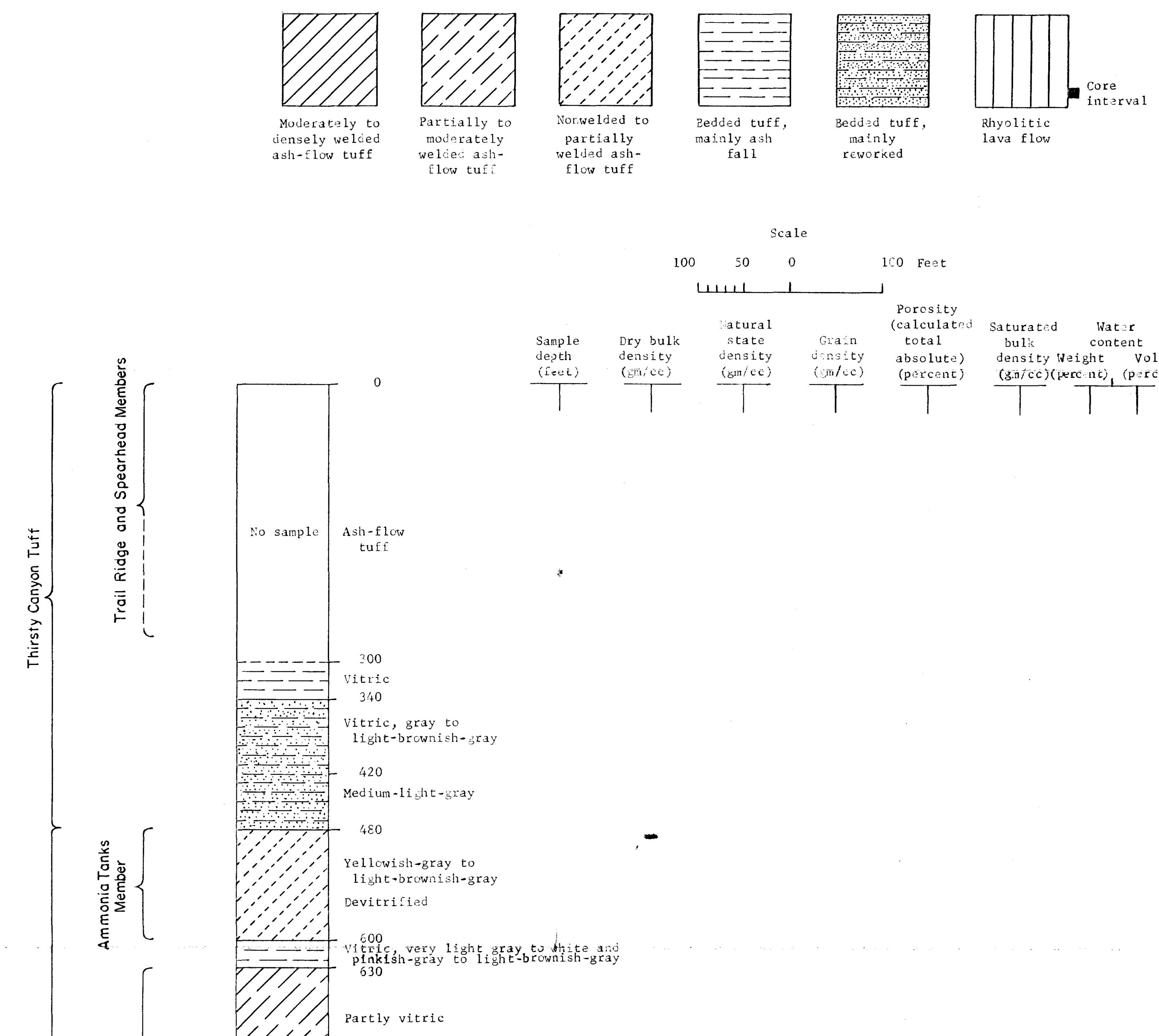
100 so 0 icale
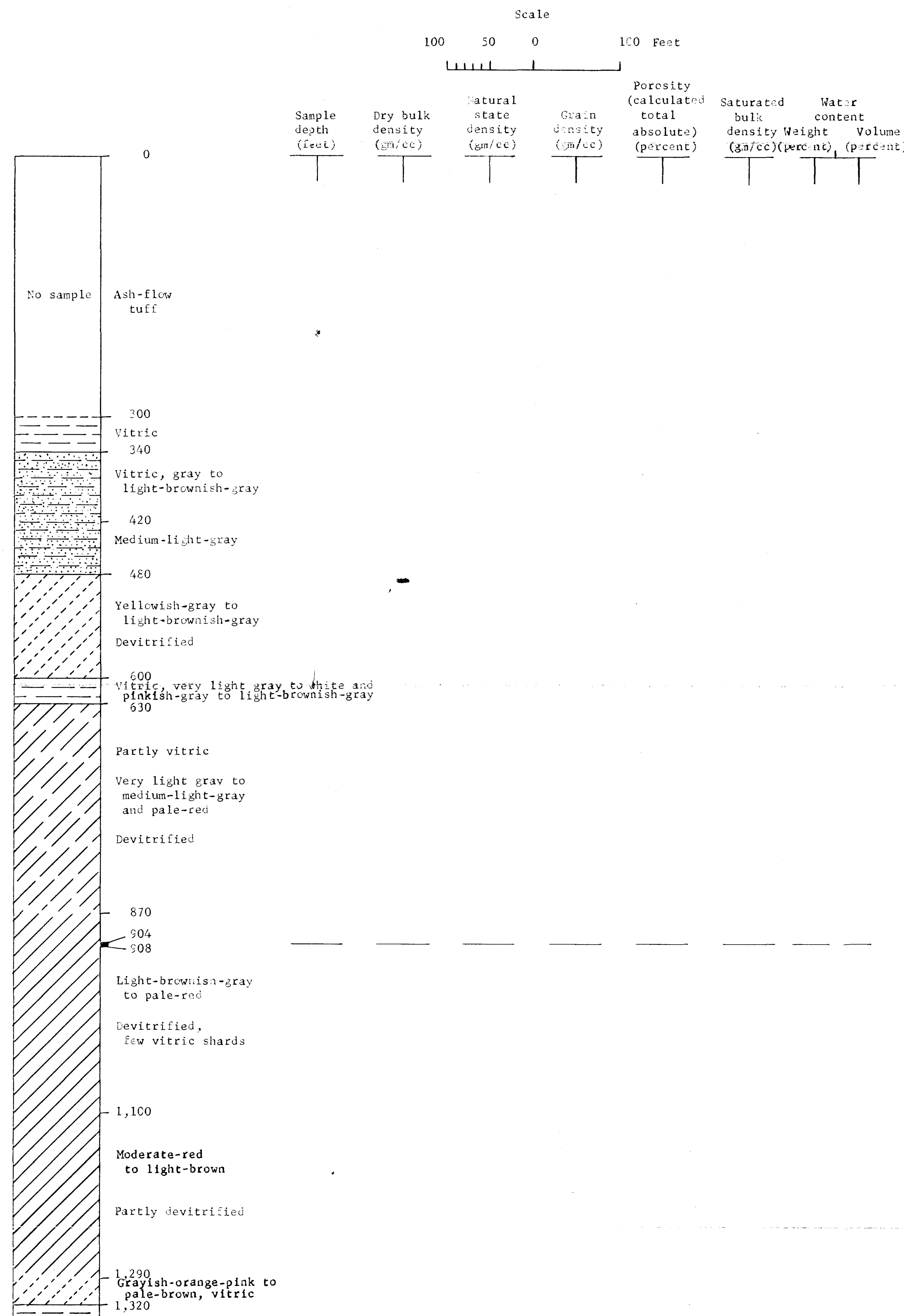